\title{
Çocukları Sokağa İten Faktörler, Karşılaştıkları Sorunlar ve Hemşirenin Rolü
}

\author{
The Factors That Push Children to the Street, the Problems They Face and the Role of the Nurse
}

\author{
Damla ÖZÇEVIK ${ }^{1}$ (iD), Ayşe Ferda OCAKÇI ${ }^{2}$ (iD
}

ÖZ

Sokakta yaşayan çocuk olgusu, dikkat çeken ancak az önemsenen evrensel sorunlardan biridir. $\mathrm{Bu}$ olgu göçler, savaşlar ve artan çarpık kentleşme gibi nedenlerle son yıllarda çok artış göstermiştir. Çocukları sokakta yaşamaya iten ailesel ve sosyoekonomik faktörler bulunmaktadır. Aile içi şiddet ve sorunlar, çocuk ihmal ve istismarı gibi çeşitli ailesel faktörlere bağlı olarak çocuklar sokağa yönelebilmektedir. Göç, çarpık kentleşme, gecekondulaşma, işsizlik ve yoksulluk ise, çocukları sokakta yaşamaya iten sosyoekonomik faktörlerdendir. Çocukların yaşadığı birçok sokak arasında sosyal ve kültürel farklılıklar olsa da yoksulluk, şiddet ve sömürü ortak bağlantıdır. Sokakta yaşayan çocuklar aile ortamı, ilgi, değer görme, sevgi, bakım ve korunmadan uzak büyümektedirler. Ayrıca, sokakta yaşamak onları riskler ve tehlikelerle karşı karşıya bırakmaktadır. Karşılaştıkları tehlike ve risklere bağlı fiziksel, sosyal ve mental olarak çeşitli sorunlar yaşayabilmektedirler. Bu çocukların çoğunluğu madde ve alkol kullanımı/bağımlılığı, eğitim eksikliği, yetersiz beslenme, cinsel yolla bulaşan hastalıklar, taşıt kazaları, sokak kavgaları, fiziksel, duygusal ve cinsel istismar ile karşılaşmaktadırlar. Sokakta yaşayan çocuklarının sağlığının korunması, sürdürülmesi ve geliştirilmesinde hemşirelerin önemli sorumlulukları bulunmaktadır. Bu derlemenin amacı; sokakta yaşayan çocukların sorunları, onları sokağa iten nedenler ve hemşirenin rolünü belirtmektir.

Anahtar Kelimeler: Çocuk, sokakta yaşayan çocuklar, hemşirelik

\begin{abstract}
The phenomenon of children living on the street is one of the universal problems that attract attention but are of limited importance. This phenomenon has increased a lot in recent years due to migrations, wars and increased skewed urbanization. There are familial and socioeconomic factors that push children to live on the streets. Depending on various factors such as domestic violence and problems child abuse and neglect, the child can be pushed into the street. Migration, skewed urbanization, squatting, unemployment and poverty are the socioeconomic factors that push children to live on the streets. Although there are social and cultural differences between the many streets where children live, poverty, violence and exploitation are common connections. Children living on the streets grow away from family environment, attention, appreciation, love, care and protection. In addition, living on the street puts them at risk and dangers. They can experience various physical, social and mental problems depending on the dangers and risks they face. The majority of these children encounter substance and alcohol use / addiction, lack of education, malnutrition, sexually transmitted diseases, vehicle accidents, street fights, physical, emotional and sexual abuse. Nurses have important responsibilities in protecting, maintaining and improving the health of children living on the street. The purpose of this review is; to indicate the problems of children living on the street, the reasons that push them to the street and the role of the nurse.
\end{abstract}

Keywords: Child, street children, nursing

\section{GIRISŞ}

Sokakta yaşayan çocuk olgusu, dikkat çeken ancak az önemsenen evrensel sorunlardan biridir. Sokak çocukları hızlı ve çarpık kentleşme süreciyle birlikte, özellikle gelişmekte olan ülkelerde kentsel alanlarda büyüyen bir sorun olmaya devam etmektedir. Bu çocuklar genellikle köprü altında, şehir pazarlarında, otobüs duraklarının yakınında, tren istasyonlarında ve diğer kalabalık alanlarda bulunmaktadırlar (1). Sokak çocukları kavramı sokak
Damla ÖZÇEVIK (ஐ)

Koç Üniversitesi, Sağllk Bilimleri Enstitüsü, İstanbul, Türkiye

e-mail: Dozcevik17@ku.edu.tr

Ayşe Ferda OCAKÇI

Koç Üniversitesi Hemşirelik Fakültesi, Çocuk Sağllğı ve Hastalıkları ABD, Istanbul, Türkiye 
çocukları ve sokakta yaşayan çocuklar olarak tanımlanabilir $(2,3)$ :

Sokak çocukları: Sokak yaşamına ekonomik olarak dahil olup, geceleri uyumak için evlerine dönmektedirler. Ancak aşırı kalabalık, yoksulluk veya evde uğradıkları fiziksel ya da cinsel istismar nedeni ile bazı geceleri sokakta geçirebilmektedirler. Türkiye'de sokak çocuklarının çoğunluğu bu gruba aittir ve sokaklarda küçük eşyalar (örneğin; peçete, su, sakı, tükenmez kalem vb.) satmaktadırlar.

Sokakta yaşayan çocuklar: Ailesi terk etmiş veya hayatta kalan aile üyeleri olmayan, kentsel alanlarda yaşayan ve uyuyan evsiz çocuklardır. Terk edilmiş binalar gibi yerlerde yalnız ya da diğer sokak çocukları ile birlikte yaşamaktadırlar.

Sokakta yaşayan çocuklar, herhangi bir yetişkin koruması olmaksızın yalnız yaşadıkları için en savunmasız grubu oluşturmaktadır (4). Dünyada kentsel ve yarı kentsel alanlarda 100 milyon sokak çocuğu yaşadığı bildirilmektedir $(5,6)$. Türkiye'de ise, en az 42 bin çocuğun sokaklarda yaşadığ ve/veya çalıştığı, resmi olmayan verilerle bu sayının 80 bine ulaştığı bildirilmiştir (7). Türkiye İstatistik Kurumu (TÜIKK) 2017 verilerine göre, 815 çocuk sokakta çalışma ve yaşama nedeniyle güvenlik birimine geldiği veya getirildiği bildirilmiştir (8).

Çeşitli sorunlarla bağlantılı olan sokaktayaşayan çocuklar olgusunu, yalnızca göç ve yoksulluk açıklayamamaktadır. Alkolizm, fiziksel, cinsel istismar ya da çocuk ihmali gibi sorunları olan yoksul ailelerdeki çocuklar, sokakta çalışmaya ve/veya yaşamaya zorlanmaktadır (3). Her sokak çocuğunun sokakta olması için en az bir nedeni bulunmaktadır. Bazı çocuklar heyecan ya da özgürlük vaadiyle sokağa yönelirken, genellikle çocuklar çaresizlik ve gidecekleri başka bir yer olmaması nedeniyle sokağa itilmektedir (9). Sokak çocuklarına yönelik gerekli müdahalelerin yapılması için bu çocukların gereksinimlerinin doğru saptanması gerekmektedir (9). Literatür incelendiğinde, bu alanda sınırlı çalışma olduğu görülmektedir $(1,5,20,23,29)$. $\mathrm{Bu}$ derlemenin amacı; çocukları sokakta yaşamaya iten nedenleri, karşılaştıkları sorunları ve hemşirenin rolünü belirtmektir.

\section{Çocukları sokakta yaşamaya iten faktörler}

Çocukluk, büyüme ve gelişmenin hızla ilerlediği bir süreçtir. Ebeveynler, çocukların yetiştirilmesi, duygusal, fiziksel, ruhsal ve sosyal yönden sağlıklı büyümelerinden sorumludur. Çocukların yaşantılarını geçirecekleri yer ailelerin yanı olmalı iken, gittikçe risklerle dolu sokaklar olmaktadır $(10,11)$. Çocuğun aile bağları ile sokağa olan yakınlığı ters ilişkilidir. Çocuğun aile bağları ne kadar güçlü ise sokağa o kadar uzak olmaktadır (12). Çocukları sokakta yaşamaya iten ailesel ve sosyoekonomik birçok faktör bulunmaktadır. Bu faktörler; göç, çarpık kentleşme, gecekondulaşma, işsizlik, yoksulluk, alkol bağımlılığı, aile içi şiddet, çocuk istismarı ve ihmali, aile içi sorunlar, zayıf aile bağları, parçalanmış aile, üvey ebeveyn, düşük ebeveyn eğitimi ve aile tarafından zorla çalıştırılmadır (Tablo 1) $(10,12-20)$.

Şekil 1. Çocukları Sokakta Yaşamaya İten Ailesel ve Sosyoekonomik Faktörler $(10,12-20)$

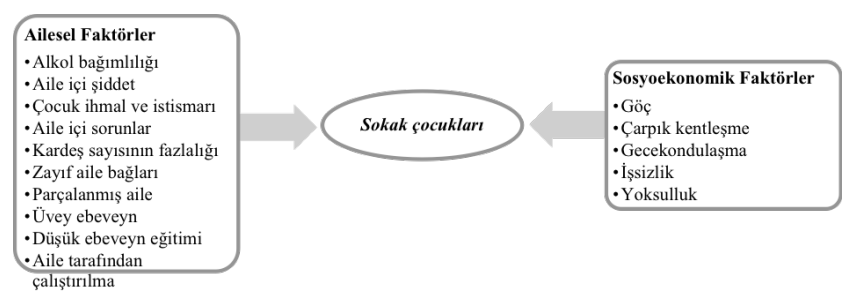

TÜIK'in 2019 verilerine göre; Türkiye nüfusunun \%27.5'ini çocuklar oluşturmaktadır (49). TÜiK'in en son yayınladığı 2017 verilerine göre; sokakta çalışma ve yaşama nedeniyle 815 çocuğun güvenlik birimine geldiği/getirildiğ rapor edilmektedir (8). T.C. Aile, Çalışma ve Sosyal Hizmetler Bakanlığı tarafindan yayınlanan "Avrupa'da en çok çocuk Türkiye'de" başlıklı raporda; 2017 ve 2020 yılı arasında 20 bin 176 çocuğun sokakta çalıştırıldığının saptandığı belirtilmektedir (50).

\section{Çocukları sokakta yaşamaya iten ailesel faktörler}

Sokakta yaşamaya itilen çocukların birçoğu açlık, alkol bağımlılığı, aile içi şiddetin yaşandığı sorunlu hanelerdeki hayatlardan kaçmaktadırlar (12, 13, 15-18). Çocuklar sokakta yaşamayı, bazen zor ve kötü aile ortamı (örneğin; üvey babanın fiziksel istismarı) gibi durumlar nedeniyle seçebilmektedirler (21, 22). Barış (2011)'ın çalışmasında; İstanbul'da sokakta yaşayan 114 çocuğun \%25'inin evi terk etmeden önce şiddet gördüğü belirlenmiştir (20). 
Aile içi sorunlar, üvey ebeveyn, parçalanmış aile, ailenin düşük sosyo-ekonomik düzeyi ve aile tarafından çalıştırılma gibi faktörler de çocuğun aile ortamından koparak, sokağa yönelmelerine neden olmaktadır $(10,19)$. Sokakta yaşayan çocukların önemli bir bölümü parçalanmış ailelerin çocuklarıdır. Barış çalışmasında, sokakta yaşayan çocukların ailelerinin \%47'sinin parçalanmış aile olduğunu saptamıştır (20).

Barış (2011) ve Subaşı Başbuğa ve Kubilay (2003) çalışmalarında, sokakta yaşayan çocukların kardeş sayılarının fazla olduğu ve ebeveynlerinin eğitim durumlarının ise düşük olduğu rapor edilmiştir $(20,23)$. Barış (2011)'ın çalışmasında, sokakta yaşayan çocukların annelerinin \%59.6'sinın ve babalarının \%35'inin okuryazar olmadığı saptanmıştır (20). Aynı çalışmada, sokakta yaşayan çocuk ailelerinin 5-9 çocuğa sahip oldukları da önemli başka bir bulgudur (20).

\section{Çocukları sokakta yaşamaya iten sosyoekonomik faktörler}

Göç, çarpık kentleşme, gecekondulaşma, işsizlik ve yoksulluk çocukları sokakta yaşamaya iten faktörlerdir. Sokakta yaşayan çocuk olgusunun en önemli nedenlerinden biri göçtür (24). Suriye'de 2011 yılında başlayan savaş nedeniyle milyonlarca insan başka ülkelere göç etmiştir. En çok mülteci barındıran ülke ise Türkiye'dir (25). Ocak 2021 tarihi itibari ile Türkiye'de yaklaşık 3.6 milyon Suriyeli göçmen bulunmaktadır. Bu göçmenlerin 1.7 milyonunu 0-18 yaş aralığındaki çocuklar oluşturmaktadır (26). Kırsal alandan kentsel alana göç eden aileler, sosyal, ekonomik ve kültürel zorluklar yaşayabilir. $\mathrm{Bu}$ ailelerin topluma yansittıkları en temel sorun; sokağa terkedilen, istismar ve/ veya ihmal edilen çocuklar olmaktadır (27). Göç, işsizliği ve bağlantılı olarak da yoksulluğu beraberinde getirmektedir. Yoksulluk, kişinin yaşamını sürdürebilmesi için gereksinimlerini karşılayamaması olarak tanımlanmaktadır. Çocuklar için yoksul bir ailede dünyaya gelmek, birçok olanaktan yoksun olmaktır. Sokakta çalışan ve/veya yaşayan çocukların ebeveynleri genellikle işsizdir ya da geçici işlerde çalışmaktadırlar. Şubaşı, Başbuğa ve Kubilay çalışmalarında, bu çocukların annelerinin \%86.7'sinin ve babaların \%34.5'inin işsiz olduğunu (23); Şişman'ın Eskişehir'de yaptığı çalışmasında ise, sokakta çalışan çocukların annelerin \%92.4'ünün ve babaların \%16.7'sinin çalışmadığını saptamıştır (19). Ailenin yoksulluk yaşaması, aile içi sorunlara temel oluşturur (20). Bu nedenle çocuklar, erken yaşlarda sokakta çalışmak ve/veya yaşamak zorunda kalabilmektedir $(12,17)$.

Çarpık kentleşme ve gecekondulaşma da sosyal, kültürel ve ekonomik olarak toplumun dengesini sarsmıştır. Türkiye'de 1950'li yıllardan itibaren hızlı bir kentleşme yaşanmıştır (20). Türkiye'de 1990 yılında kentsel nüfus oran1 \%51.3 iken, bu oran 2018 yılında \%87.9'a yükseldiği rapor edilmiştir (27).

\section{Sokakta yaşayan çocukların karşılaştı̆̆ı sorunlar}

Sokakta yaşayan çocuklar doğal gereksinimleri, aile ortam1, ilgi ve değer görme, oyun oynama gibi sevgi, bakım ve korunmadan uzak büyümektedirler (28). Sokakta yaşamak onları riskler ve tehlikelerle karşı karşıya bırakmaktadır (21). Sokakta yaşayan çocukların çoğunluğu çocuk işçiliği, çocuk kaçakçılığı, madde ve alkol kullanımı/bağımlılığı, eğitim eksikliği, yetersiz beslenme, çeşitli hastalıklar, HIV/ AIDS gibi cinsel yolla bulaşan hastalıklar, taşıt kazaları, sokak kavgaları, fiziksel, duygusal ve cinsel istismar ile karşılaşmaktadırlar (2). Çocukların yaşadığı birçok sokak arasında sosyal ve kültürel farklılıklar mevcuttur, ancak yoksulluk, şiddet ve sömürü ortak bağlantıdır (28). Çocuklar, bu durumdan kurtulmak için gruplar oluşturabilirler veya sokak çetelerine katılabilirler. Bu çeteler onları daha büyük suçlar işlemeye yönlendirebilir (9). Sokaklarda yaşayan çocuklar, hayatta kalma savaşı vermektedir ve böylesine sert bir ortamda büyük sorunlarla baş etmek zorundadırlar (21). Bu çocukların yaşadıkları sorunlar; fiziksel, psikolojik/ mental ve sosyal olmak üzere üçe ayrılmaktadır (9).

\section{Fiziksel sorunlar}

Büyüme ve gelişme: Sokak çocukları, yetersizve dengesiz beslenmeleri nedeni ile diğer çocuklara oranla daha fazla hastalanabilmektedir. Bu yetersiz beslenme, başlica anemi ve vitamin eksikliğine yol açabilmektedir (9). Afrika'da Cumber ve Tsoka-Gwegweni'nin çalışmalarına göre, sokak çocukları arasında demir eksikliği nedeniyle anemi ve A vitamini eksikliğinden dolayı görme bozukları olduğu bildirilmiştir (1). Ansari ve arkadaşlarının çalışmalarında, sokak çocuklarının yeterli protein ve vitaminden zengin beslenmedikleri, katılımcıların \%69'unun bir önceki y1l boyunca et ve balık yemedikleri bildirilmiştir (29). Bu durum çocukların büyüme ve gelişmelerine zarar verir, kronik hastalıklara, enfeksiyonlara ve diğer birçok sağlık sorununa yol açabilir $(30,31)$. 
Yaşamlarını sürdürdükleri sokaktaki hijyen yetersizliği ve hava koşulları gibi nedenler, çocuklarda kısa ve uzun süreli hastalıklara neden olmaktadır. Ayrıca, bu çocuklar birçok kazalara açık olup, ölüm riski daha yüksektir (32). $\mathrm{Bu}$ çocuklar yeterince temiz olmayan yerlerde yaşamlarını sürdürmektedirler. Tuvalet, temiz su gibi hijyen ve sanitasyon için gereksinim duydukları tesislere erişimleri sınırlıdır. Bu nedenle, sağlık sorunlarına karşı daha savunmasızdırlar ( 9 , 21).

Fiziksel yaralanmalar: Kasıtlı ve kasıtsız olarak meydana gelen fiziksel yaralanmalar, sokaktaki erkek çocuklar arasında daha yüksek olduğu bildirilmiştir (1, 9). En çok bildirilen yaralanmalar arasında ise; burkulma, kesikler, çizikler, yanıklar, sokak kavgalarından kaynaklanan morluklar ve taşıt kazaları bulunmaktadır $(33,34)$.

Cinsel ve Üreme Sağlı̆̆ Sorunları: Hem kızları hem de erkekleri etkilemektedir. Sokakta yaşayan kız çocukları, fiziksel ve cinsel istismara karşı daha savunmasızdırlar. $\mathrm{Bu}$ nedenle, cinsel yolla bulaşan hastalıklar, HIV, istenmeyen gebelikler ve güvenli olmayan kürtaj gibi cinsel ve üreme sağlığı sorunları yaşayabilmektedirler (9). Sokak çocukları arasında istenmeyen gebelikler ve etkisiz antenatal bakım önemli bir sorundur $(1,9)$.

Slk görülen hastalıklar: Sokak çocuklarının temel gereksinimleri karşılanmadığı, yetersiz hijyen olanakları ve sağlık hizmetlerine sınırlı erişimleri nedeniyle tüberküloz, cilt hastalıkları, diş problemleri ve paraziter hastalıklar sokak çocuklarında sık görülebilmektedir $(9,29)$.

\section{Sosyal sorunlar}

Yoksulluk ve eğitimsizlik: Sokakta çalışan ve/veya yaşayan çocuklar, sağlıklı bir yaşam sürdürebilmek için sınırlı temel kaynaklara sahiptirler. Genellikle sağlıklı büyüme ve gelişimleri için yiyecek alacak ve soğuk havalarda giyebilmeleri için iyi kıyafet alacak paraları bulunmamaktadır (9). Ayrıca, bu çocuklar çoğunluğu sokağa itilmekle kalmaz, hiç eğitim almamış ya da eğitim hayatlarından erken dönemde ayrılmak zorunda kalabilmektedirler (20). Afrika'da Cumber ve TsokaGwegweni tarafından yapılan bir çalışmada, sokak çocuklarının \%70'den fazlasının ilkokuldan ayrıldığ 1 belirlenmiştir (1). Eshita'nın 150 sokak çocuğuyla yaptığı çalışmasında, çocukların \%54'ünün okuma-yazma bilmediği, yalnızca \%26.7'sinin eğitim aldığını saptamıştır (35). TÜIK (2018)'in İstatistiklerle Çocuk raporunda; eğitim hizmetlerinde en önemli sorunun eğitim masrafları olduğu bildirilmiştir (36). Aynı raporda, devlet okullarında eğitim masraflarını sorun olarak görenlerin oranı $\% 44.2$ olarak bildirilmiştir (36). Eğitimin ücretsiz olduğu okullarda bile sokak çocukları üniforma, ayakkabı ve kitap satın alamamaktadırlar (9).

Ayrımcılık: Sokak çocukları eğlence yerlerinden, oyun alanlarından ayrı tutulmakta ve diğer çocukların yaptığ 1 aktivitelerden dışlanmaktadırlar (9). Yaşanılan ayrımcılığa bağlı olarak, bu çocukların özgüvenlerinin de düşük olduğu belirtilmektedir (21).

Damgalanma: Toplumdaki bazı kişiler, sokak çocuklarının kontrol edilemez ve şiddete yatkın olduğunu, madde kullanım problemleri olduğunu ve düşük ahlaklı olduklarını düşünmektedirler (9). Chireshe, Jadezweni, Cekiso ve Maphosa'nın çalışmalarında, sokaklarda yaşayan çocukların genel halktan tarafindan damgalanma ve aşağılanma yaşadıkları ortaya konmuştur (37). Bu çocukların birçoğu yiyecek gereksinimlerini çöp kutularındaki yiyeceklerle karşılamaları nedeniyle, sokakta yaşayan çocukların halk tarafından "çöpçüler" olarak adlandırıldığı ve sözlü istismar edildikleri bildirilmiştir $(21,38)$. Sokakta yaşayan çocukların bu damgalanma deneyimleri, toplumun olumsuz algılarını içselleştirmelerine neden olabilir (39).

Çocuk ihmal ve istismarı: Sokakta yaşayan çocukların karşılaştıkları diğer bir sorun, çocuk ihmal ve istismarıdır. Çocuk ihmal ve istismarının fiziksel, duygusal, cinsel istismar ve ihmal olmak üzere dört farklı tipi bulunmaktadır. Bunlardan herhangi biri çocuğun sağlığını olumsuz etkileyebilir. Bu çocuklar fiziksel, psikolojik ve sosyal izolasyon gibi çeşitli sorunlara da açıktır; ayrıca saldırganlık, umutsuzluk, uyuşturucu kullanımı ve cinsel istismar açısından yüksek risk altındadırlar $(40,41)$. Kenya'da Sitienei ve Pillay'ın sokakta yaşayan çocuklarla yaptıkları çalışmalarına göre; katılımcıların birçoğu ebeveynleri ve yakın aile üyeleri tarafindan ihmal, psikolojik, fiziksel ve sözlü istismara uğradıklarını belirtmişlerdir (38). Bu çocukların ihmal, fiziksel ve sözlü istismardan kaçmak için evlerini terk ettikleri belirlenmiştir (38). Bilgin'in çalışmasında ise, sokakta yaşadıkları süreçte çocukların \%79.3’ü fiziksel istismara, \%19.8'i cinsel istismara uğradıkları belirtilmiştir (10).

\section{Psikolojik/mental sorunlar}

Mental sağlık sorunları: Sokak çocuklarının yaşadığı stres, onları duygusal sorunlara, psikiyatrik bozukluklara ve öğrenme güçlüklerine karşı savunmasız bırakmaktadır 
$(9,18)$. Taib ve Ahmad çalışmalarında, sokak çocuklarında şizofreni, depresyon, umutsuzluk ve intihar düşüncesi gibi belirli psikiyatrik bozukluklar olduğunu bildirmişlerdir (32). Sokak çocuklarının duygusal ve davranışsal sorunlar, intihar düşüncesi ya da intihar, anksiyete, depresyon, düşük benlik saygısı, aşağılık ve umutsuzluk duyguları yaşadıkları belirtilmiştir (44). Sokakta yaşayan çocuklar, dünyanın güvenli bir yer olmadığ düşüncesine sahiptirler. Bu durum, çocukların sağlıklı kimlik gelişimini olumsuz etkiler, inanç duygusunun kaybına ve umutsuzluk duygusuna yol açmaktadır (45). Sosyal ve duygusal gelişimleri olumsuz etkilenen sokak çocuklarının, sosyal ilişkilerinin zayıf, kayg1 ve öfke düzeylerinin yüksek olduğu rapor edilmiştir (32).

Madde kullanımı ve suça itilme: Madde kullanımının temelinde; sokakta yaşanılan sorunlarla başa çıkma, uyum sağlama, şiddete dayanma, zevk, açlığ1 azaltmak, uyuyabilmek ve eğlence sayılabilir $(33,34,38,46)$. Ayrıca, sokak hayatının gerçeklerinden kaçmasını sağlayabilir (18, 32). Sokak çocukları, ucuz maddelere kolay erişebilmektedir. $\mathrm{Bu}$, aşırı doz almaya yol açabilir ve kaza, şiddet, istenmeyen gebelik riskini de artırmaktadır. Maddelerin sürekli kullanımı ise, zamanla beyin ve karaciğer hasarına neden olabilmektedir (9). Nitel bir çalışmada 17 yaşında çocuk; "uyuşturucu kullandıklarında kendilerini daha iyi ve cesur hissettiklerini, her şeyi hayal gibi hissettiklerini" belirtmiştir (21). Tudorić-Ghemo'nun çalışmasına göre; tutkal, esrar ve alkol gençler arasında en yaygın kullanılan maddelerdir ve katılımcıların tümünün bir tür madde kullandığı belirtilmiştir (18). Uyuşturucu kullanan çocuklar, dilenerek ya da sokaklarda çalışarak kazandıkları paralarını uyuşturucu satın almak için kullanırlar (21). Gelir kaynağ 1 olarak bu çocuklar genellikle para dilenirler. Ayrıca, uçucu ve uyuşturucu madde kullanan çocuklarda bunu karşılamak için hırsızlık yapma gibi suç davranışlarına girebilirler (38).

\section{Sokak Çocuklarına Yönelik Hemșirelik Girișimleri}

Sokakta yaşayan çocuklara normal bir yaşam sürmeleri için toplumdaki tüm ilgili paydaşların mevcut standartların üstüne çıkması ve bu çocukların aile, okul ve toplum içindeki refahının sağlanması gerekmektedir (38). Sokakta yaşayan çocuk olgusu, multidisipliner olarak ele alınması gerekmektedir. $\mathrm{Bu}$ ekip içerisinde hemşirenin önemli rolleri bulunmaktadır. Sokakta çocuklarının sağlığının korunması, sürdürülmesi ve geliştirilmesi hemşirelerinin sorumluluklarındandır (47). Hemşireler, öncelikle koruyucu sağlık hizmetlerine odaklanmalıdır. Çocukların yaşam alanı ev, yetiştirme yurdu ya da sokak bile olsa, yine de sağlıklı büyüme ve gelişmeleri hemşirelerin sorumluğundadır.

Çocuklar, her toplumda özenle büyütülmesi gereken, eğitilen ve mevcut imkanları en üst düzeyde kullanarak gereksinimleri karşılanması gereken geleceğin yetişkinleridir. Ebeveynlerin çocuklarını koşulsuz sevmeleri ve değer vermeleri yönünde de farkındalığın oluşturulması veya arttırılması gerekmektedir (12).

Çocuklar aile içi şiddete, istismar ve ihmale bağlı travma yaşayabilirler ve sonuç olarak sokağa itilebilirler. Bu nedenle, sokakta yaşayan çocukların hayatlarını normalleştirmek için acil müdahalelerin yanı sıra çocukları sokağa iten aile içi sorunları hafifletecek girişimler gerekmektedir (38). Hemşire, aile içi şiddeti önlemeye yönelik eğitim vermeli ve danışmanlık sağlamalıdır. Aile sağlığı merkezlerindeki hemşireler aralıklı ev ziyaretleri planlayarak, risk altındaki çocukları ve ailelerini belirlemeli, doğrudan destek (danışmanlık sağlama, eğitim verme) sağlamalıdır (23). Aile, Çalı̧̧ma ve Sosyal Hizmetler Müdürlüğü (AÇSHM), çocuğun temel gereksinimi ve bakımını sağlayabilmesi ve ailenin desteklenmesi amaciyla geçici bir süre ekonomik olarak desteklemektedir (48). Hemşire sosyoekonomik sorunlar nedeni ile çocuğun sokağa itilme riskini tespit ettiyse; aileyi ilgili AÇSHM'ne yönlendirmelidir.

Ebeveynlik becerilerinin geliştirilmesi, çocuk ihmal ve istismarı ve çocuk hakları konusunda farkındalık kazanmaları için eğitimlerle ailelerin farkındalıkları arttırılabilir. Bu sayede, hemşire çocuğun sokağa itilmesini önleyebilir. Yapılan hemşirelik müdahaleleri sadece geçici bir süre çocuğun sokağa itilmesini önlemekle kalmamalıdır. $\mathrm{Bu}$ nedenle, girişimlerin etkinliği de gözlenmelidir. Çocuklar sokakta yaşamaya itilmezse; sokakta çalışan, okulu bırakan ve suça itilen çocuk sayısı azalacak ve cinsel istismara uğrama riski de düşecektir (7).

Sokağa itilen çocukların büyüme ve gelişmeleri etkilenmekle birlikte, yaşıtları ya da yetişkinler tarafından farklı tiplerde istismarla da karşılaşabilirler. Bu durumun çocuk üzerinde kısa ve uzun vadeli olumsuz fiziksel, ruhsal ve mental etkileri olabilir. Hemşireler, çocuk istismarı ve ihmalini ve uzun vadeli etkilerini önleme ve erken müdahale stratejilerinde önemli bir rol oynamaktadır. İstismar ve ihmali önleme kapasitesi, istismar ve ihmal belirtilerini bilen, müdahale etmeye hazır, özerk, bilgi ve işgücü gerektirir. Bu nedenle, risk faktörlerini azaltmak, ailenin fonksiyonunu ve refahını iyileştirmek için toplumdaki en savunmasız üyeleri ele alan hemşirelik müdahale programları ve uygulamaları, sokak çocukları gibi diğer dezavantajlı çocuklar için de 
sağlık ve eğitim çıktılarının geliştirilmesinde etkili olacaktır (47). Sokak çocuklarının sağlık durumlarını araştıran, önleyici ve koruyucu müdahalelere odaklanan çalışmaların sayısı kısıtlıdır. Bazı çalışmalarda vurgulandığı gibi, sokak çocukları arasında morbidite ve mortaliteyi azaltmak öncelik olmalı ve bu popülasyonda yaralanmaların neden daha yüksek olduğunu daha iyi anlamak için daha fazla araştırmaya ihtiyaç bulunmaktadır $(33,48)$.

Sokakta yaşayan çocuklara belediyeler tarafindan geçici barınaklar sağlanabilmektedir. Bu alternatif konaklama yerlerinde, çocukların yaşadıkları travmanın üstesinden gelebilmeleri için çocuklara danışmanlık ve psikososyal hizmetler sunulabilir. Çocukların madde kullanımı, hırsızlık gibi olumsuz alışkanlıkları için davranış değişikliğine yönelik müdahaleler de sağlanmalıdır. Çocukları travmatize edici yaşam deneyimleriyle başa çıkmalarına yardımcı olunması, çocuk profesyonelleri tarafından sağlanmalıdır (38).

Sokak çocukları yetersiz beslenme ve barınma nedeniyle birçok hastalığa yakalanmaktadır. Yaşadıkları ortamın sokak olması nedeni ile çocuklar, çeşitli istismar türlerine karşı savunmasız kalabilmektedirler. Bu çocuklar arasında, madde kullanımı, intihar ve trafik kazaları gibi çeşitli nedenlerle ölüm de sık görülmektedir. Hemşireler sokak çocuklarının beslenme, barınma, korunma ihtiyaçlarını belirlemeli ve yaşama haklarının savunucusu olmalıdır. $\mathrm{Bu}$ çocukların bağışıklama ve sağlık durumlarının kontrolü belediyelerce görevlendirilecek çocuk sağlığı veya halk sağlı̆̆ hemşireleri tarafindan sağlanmalıdır.

Sonuç olarak, hemşireler sokakta yaşayan çocukların büyüme ve gelişmesi, hastalıkların önlenmesi, ailelerin ebeveynlik rolü geliştirmesi, aile planlaması, çocuğu disiplini etme yöntemleri ve istismar farkındalığının oluşması veya artırılması için eğitici, bakım verici, savunucu, danışman ve destek verme rolleri ile gerçekleştirmelidir.

\section{KAYNAKLAR}

1. Cumber SN, Tsoka-Gwegweni JM. The health profile of street children in africa: a literature review. J Public Health Afr. 2015; 6(2): 85-90. doi: 10.4081/jphia.2015.566

2. Ruiz HR. A study of policies and programmes in the philippines addressing the right of street children to education. Philippines. 2006: 3-14.

3. Aptekar L, Stoecklin D. Children in Street Situations: Street Children and Homeless Youth. Springer, Dordrecht. New York; 2014: 5-61.
4. Dilip Diwakar G. Life on streets: health and living conditions of children in Delhi. In: Acharya SS, Sen S, Punia M, Sunita R, eds. Marginalization in Globalizing Delhi: Issues of Land, Livelihoods and Health. Springer, New Delhi; 2017: 349368.

5. Demelash H, Addissie A. Assessment of sexual and reproductive health status of street children in Addis Ababa. Journal of Sexually Transmitted Diseases. 2013;1-20. doi: $10.1155 / 2013 / 524076$

6. Mandalazi P, Banda C, Umar E. Street children's vulnerability to HIV and sexually transmitted infections in Malawian cities. Malawi Medical Journal. 2013;25(1):1-4.

7. UNICEF, Sokakta Yaşayan ve/veya Çalışan Çocuklar. 2005. Erişim adresi: http://www.unicef.org.tr/files/bilgimerkezi/ doc/shcek-kitap-baskiya-hazir-rec4agus11.pdf. Erişim tarihi: 12.12.2020

8. TÜİK güvenlik birimine gelen veya getirilen çocuk istatistikleri. Erişim adresi: https://biruni.tuik.gov.tr/ medas $/$ ?kn=98\&locale=tr. Erişim tarihi: 14.12 .2020

9. World Health Organization (WHO). Working with street children: a training package on substance abuse, sexual and reproductive health including HIV/AIDS and STDs; 2000: Geneva: World Health Organization.

10. Bilgin R. Sokakta Çalışan Çocukları Bekleyen Risk ve Tehlikeler: Diyarbakır Örneği. Uluslararası Yönetim İktisat ve İşletme Dergisi. 2012;8(15):79-96.

11. Güngör M. Evrensel bir sorun olarak çocuk suçluluğu ve sokakta çalışan ve yaşayan çocuklar. 2008;1(1):25-43.

12. Üstüner Top F. Sokakta yaşayan ve/veya çalışan çocuklar. Türkiye Klinikleri J Pediatr Nurs-Special Topics. 2018;4(2):154-59.

13. Sharmila K, Kaur S. Experiences of abuse among street children: Nature, magnitude and practices. American Journal of Advanced Drug Delivery. 2014;2(3):387-96.

14. Nathan MA, Fratkin E. The lives of street women and children in Hawassa, Ethiopia. African Studies Review. 2018;61(1):158-84.

15. GraceyM.Childhealthinanurbanizingworld.ActaPaediatrica. 2002;91(1):1-8. doi: 10.1080/080.352.502753457842

16. Malindi MJ, Theron LC. The hidden resilience of street youth. South African Journal of Psychology. 2010;40(3):31826. doi: 10.1177/008.124.631004000310

17. McAlpine K, Henley R, Mueller M, Vetter S. A survey of street children in Northern Tanzania: How abuse or support factors may influence migration to the street. Community Mental Health Journal. 2010;46(1):26-32. doi: 10.1007/ s10597.009.9196-5

18. Tudorić-Ghemo A. Life on the street and the mental health of street children: A developmental perspective. Faculty of Arts, University of Johannesburg, South Africa., 2005.

19. Şişman Y. Sokakta çalışan çocukların yaşam koşulları ve gelecek beklentileri. Sosyal Bilimler Dergisi. 2006;2:251-76.

20. Barış İ. Sokakta Yaşayan Çocuklar ve Aileleri (İstanbul Örneği). Sosyoloji Konferansları. 2011;(39):87-114.

21. Myburgh C, Moolla A, Poggenpoel M. The lived experiences of children living on the streets of Hillbrow. Curationis. 2015;38(1):1274. doi:10.4102/curationis.v38i1.1274 
22. Alem HW, Laha A. Livelihood of street children and the role of social intervention: Insights from literature using metaanalysis. Child Development Research. 2016:1-13. doi: 10.1155/2016/3582101

23. Subaşı Başbuğa M, Kubilay G. Sokakta yaşayan/çalışan çocukların aile ve yaşadıkları konutun özellikleri. Hemşirelikte Araştırma Geliştirme Dergisi. 2003;2:34-46.

24. Güngör M. Eğitim Hakkı ve sokakta yaşayan/çalışan çocuklar: Mersin ili örneği. Mersin Üniversitesi Eğitim Fakültesi Dergisi. 2009;5(1):28-42.

25. UNICEF, Latest statistics and graphics on refugee and migrant children. 2017. Erişim adresi: https://www.unicef. org/eca/emergencies/latest-statistics-and-graphics-refugeeand-migrant-children. Erişim tarihi: 12.12.2020

26. Mülteciler Derneği Türkiye'deki Suriyeli Sayısı Ocak 2021. Erişim adresi: https://multeciler.org.tr/turkiyedeki-suriyelisayisi/. Erişim tarihi: 09.02.2021

27. TÜİK. Nüfus İstatistikleri. Erişim adresi: http://www.tuik. gov.tr/UstMenu.do?metod=temelist Erişim tarihi 12.01.2021

28. Kelly P, Grajcer B, Rigato FD. Children living on the street. Online Brazilian Journal of Nursing. 2004;2(2):31-8.

29. Ansari H, Moghaddam AA, Mohammadi M, Peyvand M, Gorgij A, Sanavi FS. Health status and life situation of street children in Zahedan, Southeast of Iran. Health Scope. 2015;4 (4):e31077. doi: 10.17795/jhealthscope-31077

30. Ayaya S, Esamai F. Health problems of street children in Eldoret Kenya. East African Medical Journal. 2001;78:6249. doi: 10.4314/eamj.v78i12.8930

31. Nzimakwe D, Brookes H. An investigation to determine the health status of institutionalised street children in a place of safety in Durban. Curationis. 1994;17(1):27-31.

32. Taib NI, Ahmad A. Psychiatric morbidity among street children in Duhok. Clinical Medicine Insights Pediatrics. 2014;8:11-6. doi: 10.4137/CMPed.S13505

33. Nada KH, Suliman EDA. Violence, abuse, alcohol and drug use, and sexual behaviors in street children of Greater Cairo and Alexandria, Egypt. AIDS. 2010;24(2):39-44. doi: 10.1097/01.aids.000.038.6732.02425.d1

34. Kudrati M, Plummer ML, Yousif NDEH. Children of the sug: a study of the daily lives of street children in Khartoum, Sudan, with intervention recommendations. Child Abuse \& Neglect. 2008;32(4):439-448. doi: 10.1016/j.chiabu.2007.07.009

35. Eshita IR. Health problems and health care seeking behavior of street children in Dhaka city. MOJ Cell Science Report. 2018;5(1):9-13. doi: 10.15406/mojcsr.2018.05.00107

36. TÜİK. İstatistiklerle Çocuk, 2018. Erişim adresi: http://www. tuik.gov.tr/OncekiHBArama.do. Erişim tarihi: 12.11.2020
37. Chireshe R, Jadezweni JM, Cekiso M, Maphosa C. Poverty: Narratives and experiences of street children in Mthatha, eastern cape, South Africa. Journal of Psychology in Africa. 2010;20(2):199-202.doi:10.1080/14330.237.2010.10820364

38. Sitienei EC, Pillay J. Life experiences of children living on Streets in Kenya: from the pot into the fire. Journal of Child \& Adolescent Trauma. 2019;12(2):201-9. doi: 10.1007/ s40653.018.0226-8

39. Schimmel N. Freedom and autonomy of street children. The International Journal of Children's Rights. 2006;14(3):21134.

40. Chimdessa A, Cheire A. Sexual and physical abuse and its determinants among street children in Addis Ababa, Ethiopia 2016. BMC Pediatrics. 2018;18(1):304. doi:10.1186/ s12887.018.1267-8

41. Murray L, Singh N, Surkan P, Semrau K, Bass J, Bolton P. A qualitative study of georgian youth who are on the street or institutionalized. International Journal of Pediatrics. 2012;2012:921604. doi: 10.1155/2012/921604

42. Richter L, Van der Walt M. The psychological assessment of South African street children. Africa Insight. 1996;26:21120.

43. Motala S, Smith T. Exposed to risk: Girls and boys living on the streets. Agenda. 2003;17(56):62-72. doi: 10.1080/10130.950.2003.9676022

44. Morakinyo J, Odejide A. A community based study of patterns of psychoactive substance use among street children in a local government area of Nigeria. Drug and Alcohol Dependence. 2003;71(2):109-16. doi: 10.1016/s03768716(03)00093-0.

45. Parry YK. Nursing and vulnerable children: our role. Austin Journal of Nursing \& Health Care. 2014;1(2): 2.

46. Bar-On, A., Criminalising survival: images and reality of street children. Journal of Social Policy. 1997;26:63-78.

47. Haylı, ÇM, Akca Sümengen A, \& Ocakçı AF. Sokakta Çalışan Çocukların Sağlığının Korunmasında Hemşirelerin Rolü. Kocaeli Üniversitesi Sağlık Bilimleri Dergisi. 2019; 5(3): 177-181.

48. TC. Aile, Çalışma ve Sosyal Hizmetler Bakanlığı. Sosyal ve Ekonomik Destek (SED) Hizmeti. Erişim adresi: https:// www.ailevecalisma.gov.tr/tr-tr/sss/cocuk-hizmetleri-genelmudurlugu/sed-hizmeti/ Erişim tarihi: 09.01.2021

49. TÜİK. İstatistiklerle Çocuk, 2019. Erişim adresi: https:// tuikweb.tuik.gov.tr/PreHaberBultenleri.do?id=33733 Erişim tarihi: 15.02.2021

50. T.C. Aile, Çalışma ve Sosyal Hizmetler Bakanlığı. Avrupa'da en çok çocuk Türkiye'de. 2020. Erişim adresi: https:// ailevecalisma.gov.tr/chgm/haberler/avrupa-da-en-cokcocuk-turkiye-de/ Erişim tarihi: 15.02.2021 